Erratum

\title{
Erratum: Liang, X., et al. Applying Deep Learning to Clear-Sky Radiance Simulation for VIIRS with Community Radiative Transfer Model-Part 2: Model Architecture and Assessment. Remote Sens. 2020, 12, 3825
}

\author{
Xingming Liang $1, * \mathbb{D}$ and Quanhua (Mark) Liu ${ }^{2}$ \\ 1 Earth System Science Interdisciplinary Center, University of Maryland, College Park, MD 20740, USA \\ 2 Center for Satellite Applications and Research (STAR), National Environmental Satellite, Data, and \\ Information Service (NESDIS), National Oceanic and Atmospheric Administration (NOAA), College Park, \\ MD 20740, USA; quanhua.liu@noaa.gov \\ * Correspondence: xingming.liang@noaa.gov; Tel.: +1-301-683-3362
}

check for updates

Citation: Liang, X.; Liu, Q. Erratum: Liang, X., et al. Applying Deep Learning to Clear-Sky Radiance Simulation for VIIRS with

Community Radiative Transfer Model-Part 2: Model Architecture and Assessment. Remote Sens. 2020, 12, 3825. Remote Sens. 2021, 13, 467. https: / /doi.org/10.3390/rs13030467

Received: 25 January 2021 Accepted: 26 January 2021 Published: 29 January 2021

Publisher's Note: MDPI stays neutral with regard to jurisdictional claims in published maps and institutional affiliations.

Copyright: (c) 2021 by the authors. Licensee MDPI, Basel, Switzerland. This article is an open access article distributed under the terms and conditions of the Creative Commons Attribution (CC BY) license (https:// creativecommons.org/licenses/by/ $4.0 /)$.
The authors would like to make the following correction of [1]:

In the original article, Reference 28 was incorrect, because Part 1 was accepted by Remote Sensing later than Part 2, but the title of Part 1 was changed during the review. It should be changed from

Liang, X.; Liu, Q. Development of Fast and Robust Clear-sky Mask for VIIRS using Deep Neural Network. Remote Sens. under review.

into:

Liang, X.; Liu, Q. Applying Deep Learning to Clear-Sky Radiance Simulation for VIIRS with Community Radiative Transfer Model-Part 1: Develop AI-Based Clear-Sky Mask. Remote Sens. 2021, 13, 222.

Conflicts of Interest: The authors declare no conflict of interest.

\section{Reference}

1. Liang, X.; Liu, Q. Applying Deep Learning to Clear-Sky Radiance Simulation for VIIRS with Community Radiative Transfer Model-Part 2: Model Architecture and Assessment. Remote Sens. 2020, 12, 3825. [CrossRef] 